\title{
As influências de Nicolau Maquiavel na ética e política
}

Maquiavel é um pensador italiano de grande relevância na concepção de fazer política, viveu no Século XIV. Alguns autores o caracterizam como aquele que promove mudanças radicais. É abordado nesta pesquisa de caráter bibliográfico, algumas considerações sobre a vida e obra de Nicolau Maquiavel, como também as principais contribuições do Filósofo no pensar sobre a Política, em seu pleno exercício e o poder. A proposta é caracterizar, o pensamento deste filósofo, recorrendo principalmente a sua obra basilar, O Príncipe. No decorrer da discussão poderá ser identificada a relação entre a ética e política em seu pensamento, e expressões usadas por Maquiavel como virtù, Fortuna, e a maneira de compreender o poder: tomada e manutenção.

Palavras-chave: Maquiavel; Ética; Política; Virtude; Poder.

\section{The influences of Niccolò Machieavelli in ethics and politics}

Machiavelli is an Italian thinker of great relevance in the conception of making politics, lived in the XIV century. Some authors characterize it as one that promotes radical changes. It is approached in this bibliographical research, some considerations about the life and work of Niccolò Machiavelli, as well as the main contributions of the Philosopher in thinking about Politics, in its full exercise and power. The proposal is to characterize, the thought of this philosopher, resorting mainly to his basilar work, The Prince. In the course of the discussion the relationship between ethics and politics in his thinking can be identified, and expressions used by Machiavelli as virtù, Fortuna, and the way of understanding power: making and maintenance.

Keywords: Machiavelli; Ethic; Politics; Virtue; Power.

Topic: Filosofia Política

Reviewed anonymously in the process of blind peer
Received: $\mathbf{1 1 / 0 4 / 2 0 1 9}$

Approved: 10/06/2019
Tayronne de Almeida Rodrigues (10)

Faculdade de Juazeiro do Norte, Brasil

http://lattes.cnpq.br/8602100500602426

http://orcid.org/0000-0001-9378-1456

tayronnealmeid@gmail.com

João Leandro Neto (iD)

Faculdade Entre Rios do Piauí, Brasil

http://lattes.cnpq.br/0489242460344918

http://orcid.org/0000-0003-1738-1164

joaoleandro@gmail.com

Aluísio Vasconcelos de Carvalho

Faculdade Guaraí, Brasil

http://lattes.cnpq.br/5200758055263996

http://orcid.org/0000-0002-3793-3133

aluisiovasconcelos@gmail.com

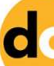

DOI: 10.6008/CBPC2674-6654.2019.001.0002
Referencing this:

RODRIGUES, T. A.; LEANDRO NETO, J.; CARVALHO, A. V.. As influências de Nicolau Maquiavel na ética e política. Humanum Sciences, v.1, n.1, p.11-25, 2019. DOI: http://doi.org/10.6008/CBPC26746654.2019.001.0002 


\section{INTRODUÇÃO}

Antes de Maquiavel, os teóricos da política tinham escrito sobre coisas tais como os deveres do governante, que tipo de pessoa constituiria o príncipe ideal, e qual seria a forma mais desejável de sociedade. Mas, por mais sábios e profundos que fossem os melhores desses escritos, eles não tratavam das atividades políticas do dia a dia. Em contraste com tudo isso, Maquiavel propôs-se a narrá-las como são.

Estamos acostumados a ouvir as expressões como maquiavélico e maquiavelismo, as expressões geralmente são usadas quando alguém deseja referir-se principalmente à política. $O$ termo maquiavélico geralmente é demonizado e atribuído a uma pessoa desleal, hipócrita e fingida. É comum, de acordo com o senso comum, condenarmos outros seres humanos a partir de uma visão superficial de sua conduta, no caso de Nicolau Maquiavel, a partir de sua obra.

Em "O Príncipe", tal afirmativa é concretizada, já que o autor não é bem interpretado ou compreendido com mais atenção. Esta forma de interpretação já vem desde longa data, isto se dá pela grandiosidade da obra de Maquiavel.

Tudo o que Maquiavel estava fazendo era deixar a honestidade intelectual incidir sobre as realidades da política. Tal como os novos cientistas tentavam conscientemente, contra todo o peso da tradição cristã, desenvolver uma ciência isenta, assim Maquiavel tentou desenvolver uma teoria política isenta.

As informações foram obtidas a partir de pesquisas bibliográfica, de cunho exploratório e de natureza investigativa. Segundo Gil (2011), a pesquisa é feita mediante conhecimentos acessíveis com a execução de métodos e técnicas de investigação.

Fonseca (2002), afirma que "a pesquisa bibliográfica é feita a partir do levantamento de referências teóricas já analisadas, e publicadas por meios escritos e eletrônicos, como livros, artigos científicos, páginas de web sites".

O objetivo deste estudo é caracterizar, o pensamento de Maquiavel, recorrendo principalmente a sua obra basilar, O Príncipe. No decorrer do trabalho poderá ser identificada a relação entre a ética e a política em seu pensamento.

\section{DISCUSSÃO TEÓRICA}

\section{Vida e obra de Nicolau Maquiavel}

Pertencente a uma família da alta burguesia de Florença, nascia em três de maio de 1469, Nicolau Maquiavel, um teórico político que mudaria a forma de se pensar em Estado há vários séculos. Filho de advogado recebeu do pai excelente educação em humanidades, fato que explica sua ligação com a familiaridade com a história greco-romana.

Com um vasto conhecimento, algo que era raro na época, não tardou muito para ocupar cargos políticos relevantes na administração pública. Com 29 anos, Maquiavel exerceu o cargo público de Secretário da Segunda Chancelaria do Estado, mesmo ano, aliás, da deposição do monge Savonarola do Governo de 
Florença, condenado à morte na fogueira. Neste período a sua produção intelectual esteve voltada, sobretudo, para questões de ordem prática.

Dessa forma, as suas obras constituem-se, então, principalmente de cartas, legações e de certo número de breves escritos, dentre os quais podemos citar "O Retrato sobre as coisas da França" e o "O Retrato das coisas da Alemanha". Ambos trabalhos resultam de suas observações enquanto esteve em missão diplomática.

Até 1513, quando os Médicis voltaram a Florença, a vida de Maquiavel esteve sempre ligada diretamente à administração estatal tanto que chegou a incumbir-se da formação de uma milícia nacional, que liberasse Florença da incômoda necessidade dos condottieres, que com suas tropas mercenárias infestavam todo o território italiano. Entretanto, quando os Médicis retornaram a queda deste hábil administrador foi inevitável devido as suas divergências políticas com aqueles que agora detinham o poder. Maquiavel acabou sendo desterrado para sua pequena herdade nos arredores de São Casciano.

Entretanto, foi exilado que Maquiavel resolveu transformar todo o seu conhecimento prático em obras de cunho político. Obras como a "A Arte da Guerra", "Discursos sobre a Primeira Década de Tito Lívio" vão mostrar trazer à tona todo o seu vasto conhecimento referente à arte de governar. Entretanto, a sua principal obra que o elevaria a grupo dos grandes escritores da humanidade que no seu original chama-se "De Principatibus" (Dos Principados), ou, como se tornaria universalmente conhecida, "O Príncipe".

A partir de 1516, Maquiavel começa a frequentar os jardins Orti Oricellari, em Florença, lugar onde reunia um grupo de jovens da alta sociedade da época com intuito de discutir questões de caráter político. Assim, estimulado pelos seus companheiros de discussão a continuar a colocar sua experiência política no papel, em 1917 produz os "discursos sobre a primeira década de Tito Lívio", obra na qual tem como objetivo fazer uma análise de várias questões relativas ao governo republicano.

Com a morte de Lourenço II em 1520, Júlio de Médici assumiu o poder em Florença. Ele via Maquiavel com melhores olhos que seus antecessores e o contratou como historiador da República para escrever uma História de Florença, obra a qual dedicaria os sete últimos anos de sua vida. Nesse mesmo ano, ele estava ocupado escrevendo A Arte da Guerra (1519-1520). E é a partir de uma viagem a trabalho a Lucca que ele escreve a "Vita di Castruccio Castracani da Lucca" (1520). (RIDOLFI, 2003)

Entretanto, segundo Paul Larivaille em sua obra "A Itália do Tempo de Maquiavel", este fato serviu apenas para torná-lo suspeito aos olhos dos republicanos, quando sete anos mais tarde foram os Médicis novamente expulsos. Além de sua vasta obra onde faz análises sobres às questões referentes às relações que permeiam estado política e poder, Maquiavel também se ateve a produções teatrais destacando-se Madrágora, obra-prima do teatro italiano, a novela Belfagor, além das Decenais e de alguns poemas.

Melancólico, Maquiavel falece aos 58 anos, no dia 21 de junho de 1527, não conseguindo reaver o seu antigo cargo político junto ao regime republicano tendo a nítida percepção de ter fracassado na vida, sem suspeitar, contudo, da imortalidade que haveria de granjear por meio de sua pequena obra-prima, publicada quatro anos após sua morte. 


\title{
A situação política na Itália do século XIV ao Renascimento
}

Apesar de Nicolau Maquiavel ter vivido relativamente pouco, nasceu em 1469 e faleceu em 1527, o período o qual este italiano teve o privilégio de presenciar pode ser caracterizado como um dos momentos de grande efervescência cultural e científica de todos os tempos. O seu amadurecimento intelectual coincidiu com um dos momentos mais expressivos da renascença na Europa e principalmente na Itália.

Maquiavel cresceu junto com a Renascença, pois quando ele tinha apenas 17 anos Boticelli já havia acabado de pintar "O Nascimento de Vênus", obra-prima desse período. Quando completara 23 anos os europeus chegaram ao Novo Mundo, seus 37anos coincidiram com a obra capital de Leonardo da Vinci, "Monaliza". Dessa forma, é evidente que muito da formação erudita que Maquiavel recebeu está diretamente ligada a este momento ímpar que ele teve o privilégio de participar. Entretanto, apesar a efervescência cultural do período a Itália apresentava sérios problemas na sua organização política.

\begin{abstract}
Por trás dessa Itália renascentista, porém, escondia-se outra península, marcada pela violência, corrupção, assassinatos políticos e escândalos sexuais envolvendo até papas. Sem levar em conta a turbulência do período, não há como entender a natureza dos conselhos de Maquiavel em O Príncipe - clássico do pensamento político ocidental. Fora de contexto, a obra, espécie de manual realista de auto-ajuda para governantes, parece cruel - ou "maquiavélica", termo que virou sinônimo de qualquer trama ardilosa para se atingir um objetivo. Poucos se dão conta de que durante a vida de Maquiavel a própria Itália não existia. (LARIVALLE, 1991)
\end{abstract}

Neste conglomerado de divergências, quatro estados se destacavam: Os Estados Pontifícios, onde se destacava a cidade de Roma sede do poder da Igreja Católica e, portanto, importantíssima não apenas para Roma, mas para todo o mundo Ocidental. Além desse, a República de Veneza, o Ducado de Milão e o Estado Florentino também se destacavam pelo seu poderio econômico e militar. Esses estados maiores, por deter a hegemonia em suas respectivas regiões, acabavam por submeter os estados menores e, portanto, mais fracos ao seu poder.

Nesse contexto, de forte descentralização acabava sendo um terreno fértil para convulsões políticas. Sendo assim, a queda de governos era comum e o clima de insegurança reinava sobre a península, já que nenhum estado detinha poder suficiente para subjugar e conseguir centralizar o poder. Dessa forma, a península acabava por se tornar presa fácil para frequentes invasões de seus vizinhos, principalmente Espanha e França e esta situação ainda se tornava pior, haja vista que os exércitos desses estados peninsulares se caracterizavam por milícias corruptas.

Esta situação de degradação moral ultrapassava os muros de Roma onde assassinatos e escândalos de caráter sexual eram constantes na Santa Sé. São inúmeros os eventos que mostram que integrantes da Igreja estavam mais preocupados com a vida terrena do que com o campo espiritual. O Papa Alexandre VI, por exemplo, chegou ao ponto de promover um irmão de sua amante a cardeal e sobre este mesmo papa recaia suspeitas de assassinatos e uma série de atos imorais com intuito apenas de angariar mais poder.

Em suma, a corrupção predominava no clero e certamente esta conjuntura deixava intelectuais atentos às questões que o rodeavam, como Maquiavel, ainda mais revoltados e obstinados a promoverem uma mudança radical. 
Filósofos, historiadores, poetas, dramaturgos, retóricos, matemáticos, astrônomos, médicos, biólogos, arquitetos, pintores, músicos começam a redescobrir obras da antiguidade (...). Esparta, Atenas e Roma são tomadas como exemplos da liberdade republicana. Imitá-las é voltar a valorizar a política como expressão da mais alta capacidade humana e erguer a vida ativa contra o ideal de vida contemplativa, valorizado pela Igreja, isto é, a vida espiritual do sábio contemplativo e solitário que se preocupa com a vida futura no outro mundo sem se preocupar com a vida presente neste mundo. Fala-se agora na liberdade republicana e na vida política com as formas mais altas da dignidade humana. (CHAUÍ, 2010)

É importante citar que o poder da Igreja não se restringia apenas aos membros do clero, mas a força desta instituição era tamanha que elementos da teologia serviam de base ideológica nas formulações teóricas da política nesse período. Nesse sentido, a filósofa Marilena Chauí afirma em sua obra "Introdução a Filosofia" que a política medieval se encontra fundamentada em Deus ou na ordem natural do mundo criada por Ele.

Além disso, o objetivo da política nesse período deveria ser o bem comum, realizada pela boa comunidade harmoniosa e sem conflitos. Surgia assim à figura do bom governo permanentemente justos e ordeiros inspirados também na antiguidade clássica que como pode se perceber era uma utopia se analisarmos a estrutura estatal da época.

E essa ideologia política que norteava os estados formadores da península ibérica fez surgir formas de governo muito avançadas se analisarmos em relação à forte tendência centralizadora e absolutista que prevalecia em boa parte da Europa. Exemplo disso é dado pela cidade-estado de Florença que era uma república onde famílias mais abastadas disputavam ardentemente o poder. O sistema político em Florença caracteriza-se pela rotatividade, pois em no máximo quatro meses os mandatários eram trocados. Contudo, essa rotatividade não significava que o poder era exercido por todos, já que um grupo de famílias poderosas se alternava no poder. Este contexto era propício para o surgimento de convulsões sociais que desestabilizavam ainda mais as frágeis colunas governamentais desses estados.

Entretanto, qual era o elo que unia estes estados que eram tão distintos entre si? Nessa perspectiva o historiador Paul Larivaille vai relatar em seu livro "A Itália de Maquiavel" que apesar de diferenças capitais os estados formadores dessa península tinham um passado que os ligava. Estes estados eram herdeiros do legado romano e não é interessante esquecer-se que o período ao qual é feito referência trata-se do auge da renascença, movimento esse que buscava reviver aquele legado Romano. Esse passado de glórias o qual era novamente colocado em evidência pelos renascentistas logo foi utilizado na defesa da unificação dessa importante península europeia.

É relevante mencionar que apesar das questões históricas que ligavam os estados formadores dessa região, o contexto daquele período era mais propício para a desagregação do que para a unidade deles. A própria Santa Sé não detinha poder para unificar todos esses estados ao seu redor, mas tinha força e influência para frustrar os planos de outros que quisessem fazê-lo. Dessa forma, a futura Itália, no século XV, caracteriza-se por um quadro de extrema desagregação política completamente permeada por pequenos estados com diversos níveis de desenvolvimento econômico e social.

Maquiavel observou, porém, que havia uma distância entre o ideal de política e realidade política da sua época. Escreveu então O Príncipe (1513-1515) com o propósito de tratar a 
política como ela se dá, ou seja, pretender fazer não uma teoria da política ideal, mas, ao contrário compreender e esclarecer a política real. Dessa forma, Maquiavel afastou-se da concepção idealizada de política. Centrou suas reflexões na constatação de que o poder político tem como função regular as lutas e tensões entre os grupos sociais, os quais, em seu entendimento, eram basicamente dois: o grupo dos poderosos e o povo. Essas lutas e tensões existiam sempre, de tal forma que seria ilusão buscar um bem comum para todos. (CHAUÍ, 2010)

Foi nesse contexto que desenvolveu Nicolau Maquiavel sua percepção sobre a política, e, se nas palavras do historiador italiano Benedetto Croce "todo homem é filho de seu tempo", esse pensador florentino com espírito lúcido conseguiu observar o conturbado contexto em que viveu da forma mais objetiva possível. Essa observação profunda de seu contexto fez com que ele conseguisse extrair lições que até hoje conseguem estar presente no debate político contemporâneo.

\section{Século XV e os primeiros pensamentos políticos de Maquiavel}

Ao analisar a vida e a obra deste fantástico pensador italiano perceberemos que muitas vezes ocorre certo preconceito com relação aos seus ensinamentos transcritos em suas obras. Um exemplo disso é o termo maquiavélico que, sem nenhuma dúvida, tem sua origem no nome Maquiavel. Por meio desse designamos tudo aquilo que é pérfido, é imoral. No entanto, cabe perguntar se tal qualificativo pode ser aplicado à pessoa e à obra desse secretário florentino:

Para Maquiavel, na ação política não são os princípios morais que contam, mas os resultados. (...) O filosofo faz uma análise não moral dos atos de diversos governantes procurando mostrar em que momentos suas opções foram interessantes para a manutenção do poder político. Deve-se a essa fraqueza depuradora o uso pejorativo do adjetivo maquiavélico, que designa o comportamento "sem moral". Mas o que se deve reter do pensamento de Maquiavel é que ele inaugura um novo patamar de reflexão política que procura compreender e descrever a ação política tal como ela se dá realmente. Seu mérito é ter compreendido que a política, no início da Idade Moderna, desvincula-se das esferas da moral e da religião, constituindo-se em uma esfera autônoma. (CONTRIM, 2010)

Historicamente, esse preconceito quanto à pessoa de Maquiavel certamente está ligado às polêmicas contidas em suas obras, o que fez produzir os mais diversos juízos sobre seu respeito. No entanto, a aversão a sua obra só ganhou caráter sistemático por volta de 1550 quando a Igreja resolveu incluir sua obra na lista de livros proibidos, $\mathrm{O}$ Índex. Além disso, a condenação prematura à sua obra também foi e é realizada por aqueles que tinham contato com os escritos desse pensador apenas de segunda mão.

Esses fatos fizeram nascer uma perspectiva que coloca o termo Maquiavel a designar tudo que é imoral. Contudo, não nos interessa tratar da maneira na qual Maquiavel é tratado e representado no imaginário das pessoas, mas entender sim, de fato, o que a obra desse grande pensador italiano traz de fato.

Neste sentido, pode-se conceber que obra de Maquiavel está dividida em duas formas principais. A primeira pode entender como um manual de técnicas com o objetivo de conquista e a manutenção do poder, podendo ser percebida esta característica de diferenciação na objetividade e caráter descritivo dessas obras. A segunda coloca o escritor como um teórico da razão de estado, doutrina essa que coloca o secretário florentino como teórico da força.

Segundo Silva (2010) em qualquer uma dessas interpretações de sua obra é apresentada como uma filosofia política completamente despida de valoração moral. Entretanto, devemos lembrar que as críticas 
impostas por Maquiavel a estrutura estatal é relacionada ao seu próprio tempo, tempo esse que daria menos importância liberdade civil típica de um regime republicano se essa supressão de direitos vier acompanhada de uma estabilidade estatal típica dos regimes monárquicos. Dessa forma, percebe-se que a obra desse grande pensador florentino não vem contrapor moralidade e pensamento político, mas sim mostrar que a manutenção do estado é mais importante que a ética.

Contudo, podem-se encontrar mais algumas especificidades na obra de Maquiavel. A obra desse secretário florentino também pode ser vista de outras óticas distintas: o Príncipe e claro os Discursos. Mesmo não sabendo detalhadamente a ordem cronológica das referidas obras, o fato na sua obra capital O Príncipe, Maquiavel quer mostrar a um monarca as vias que deveria seguir para conquistar e conservar um estado. $\mathrm{O}$ objetivo dessa obra já fica claro na sua dedicatória:

As mais das vezes costumam aqueles que desejam granjear as graças de um príncipe trazerIhe os objetos que lhes são mais caros, ou com os quais o veem deleitar-se; assim, muitas vezes, ele é presenteado com cavalos, armas, tecidos de ouro, pedras preciosas e outros ornamentos dignos de sua grandeza. Desejando eu oferecer a Vossa Magnificência um testemunho qualquer de minha obrigação, não achei, entre os meus cabedais, coisa que me seja mais cara ou que tanto estime quanto o conhecimento das ações dos grandes homens apreendido por uma longa experiência das coisas modernas e uma contínua lição das antigas; as quais, tendo eu, com grande diligência, longamente cogitado, examinando-as, agora mando a Vossa Magnificência, reduzidas a um pequeno volume. (...)

Tome, pois, Vossa Magnificência este pequeno presente com a intenção com que eu o mando. Se esta obra for diligentemente considerada e lida, Vossa Magnificência conhecerá o meu extremo desejo que alcance aquela grandeza que a Fortuna e outras qualidades Ihe prometem. E se Vossa Magnificência, do ápice da sua altura, alguma vez volver os olhos para baixo, saberá quão sem razão suporto uma grande e contínua má sorte. (MAQUIAVEL, 1513)

Entretanto, dando um sentido mais revolucionário a esta obra podemos encará-la com um veículo de denúncia para explicitar os mecanismos de poder sobre os quais se assentava um estado principesco. Além disso, em O Príncipe, Maquiavel faz análise do comportamento humano frente a meio social especificamente em se tratando de relações de poder.

É que os homens geralmente são ingratos, volúveis, simuladores, covardes e ambiciosos de dinheiro, e, enquanto lhes fizeres bem, todos estão contigo, oferecem-te sangue, bens, vida, filhos, como disse acima, desde que a necessidade esteja longe de ti. Mas, quando ela se avizinha, voltam-se para outra parte. E o príncipe, se confiou plenamente em palavras e não tomou outras precauções, está arruinado. Pois as amizades conquistadas por interesse, e não por grandeza e nobreza de caráter, são compradas, mas não se pode contar com elas no momento necessário. E os homens hesitam menos em ofender aos que se fazem amar do que aos que se fazem temer, porque o amor é mantido por um vínculo de obrigação, o qual, devido a serem os homens pérfidos, é rompido sempre que lhes aprouver, ao passo que o temor que se infunde é alimentado pelo receio de castigo, que é um sentimento que não se abandona nunca. Deve, portanto, o príncipe fazer-se temer de maneira que, se não se fizer amado, pelo menos evite o ódio, pois é fácil ser ao mesmo tempo temido e não odiado, o que sucederá uma vez que se abstenha de se apoderar dos bens e das mulheres dos seus cidadãos e dos seus súditos. (MAQUIAVEL, 1513)

Em síntese, em o Príncipe Maquiavel diz ocupar-se apenas dos principados, visto que posteriormente tratara das repúblicas. Nos Discursos, a outra parte de sua obra, trata da república e, portanto, de um governo livre, liberdade essa que envolve tanto igualdade de todos perante leis, quanto à possibilidade de participação dos cidadãos na determinação das pessoas na vida do estado. Neste sentido, o secretário 
florentino faz com os discursos uma análise não só dos modelos de república, como também vai mostrar quais são suas instituições fundamentais para que esta tenha sucesso. Constituindo assim os Discursos um manual de manutenção de uma república forte coesa e por isso mais livre.

Dessa forma, novas análises referentes aos escritos de Nicolau Maquiavel vêm a refutar todo aquele preconceito existente ao que se refere à obra desse grande pensador. A obra desse grande pensador italiano não é apenas em um manual a quem se propõe conquistar e governar, mas principalmente àqueles que se arriscam na difícil tarefa de se entender como o poder estatal se constitui na sociedade.

\section{Afinal, o que é "o príncipe"?}

O livro "O Príncipe" não é apenas a principal obra desse grande pensador italiano Nicolau Maquiavel, mas é também uma das principais obras literárias de toda história no entendimento de como a política é sistematizada. Seus ensinamentos são tão universais que muitos políticos contemporâneos buscam esse "manual político" mesmo fazendo vários séculos que esta obra foi escrita.

Maquiavel buscava nessa obra soluções para problemas do seu período que, como já foi citado, caracterizava-se por uma grande fragmentação territorial e desorganização política. Por isto, muitas das críticas feitas a esta obra caem por terra ao lembrar que as concepções apresentadas em "O Príncipe" devem ser vistas como convenientes à sua época e ao contexto vivido pelo autor. Nesse sentido, a obra de Maquiavel não pode ser vista apenas como uma forma de ser ver política, mas também um modo de se olhar a Itália e seus problemas naquele período.

No entanto, para compreender o impacto que tem a obra de Nicolau Maquiavel na concepção política da época se faz necessário analisar a ideologia política presente. A obra "O Príncipe" poder ser vista como um marco para uma nova concepção política e observar como esta era entendida por Maquiavel.

A concepção de Política no período medieval e renascentista apesar de diferenças, em muitos casos até paradoxais, tem como base ideológica uma visão cristã. Isto significa que para todas elas a relação entre religião e política é algo indissolúvel e permanente.

É verdade que as teorias medievais são diretamente teocráticas (o poder pertence apenas a Deus, que o concede a alguém por um favor especial) ou indiretamente teocráticas (a origem do poder está na natureza social do homem, mas o fundamento último do poder político encontra-se na lei divina revelada) enquanto os renascentistas procuram evitar a ideia de que o poder seria uma graça ou um favor divino e que se encontra determinado diretamente pela lei divina. (CHAUÍ, 2010)

Silva (2010) nos diz que a concepção política do período, apesar de recusar a teocracia, aceita outra ideia cristã, a de que o poder político só pode ser legitimado se for justo. No entanto, um governo só pode ser justo se estiver de acordo com a vontade de Deus. Dessa forma, como afirma Marilena Chaú, elementos da teologia continuam a exercer influência nas formulações das teorias políticas, mesmo como na renascença. Nesse sentido podem-se elencar alguns aspectos provenientes dos elementos da teologia presentes tanto a base ideológica da política medieval quanto no período renascentista.

Primeiramente, é possível perceber que é encontrado na política um fundamento anterior e exterior a própria política. Em outras palavras, nesse período o fundamento da política está em Deus diretamente ou 
indiretamente colocada aos homens. A política consiste assim em desígnios de Deus para manter a paz entre os homens.

Outro aspecto relevante quanto à concepção da finalidade da política percebe-se que ela é vista no período como uma instituição una e indivisa, cuja finalidade é realizar o bem comum ou justiça. Nesse sentido, a boa política é feita pela boa comunidade, harmoniosa pacífica e ordeira. Sendo que qualquer coisa que venha a interferir nesta ordem é vista como perigosos frutos de homens perversos e sediciosos que devem ser afastados do poder.

Assim, a boa comunidade deve estar assentada na figura do bom governo, isto é, um príncipe virtuoso e racional que sempre é justo e busca a harmonia entre os membros do seu povo. Ao observar esses aspectos anteriormente apresentados referentes às características da política, podemos perceber alguns aspectos que colocam a obra de Maquiavel, principalmente sua obra capital, "O Príncipe", como revolucionária, pois com elas nasce o pensamento político moderno.

Na verdade, o primeiro passo a ser dado para o real entendimento das concepções desse pensador italiano é retirar internamente qualquer rastro de hipocrisia e entender e não ver as coisas como elas deveriam ser, mas sim como elas realmente são. Nicolau Maquiavel faz essa tarefa em suas reflexões sobre a política da sua época enfatizando primeiramente a finalidade desta e não as suas qualidades necessárias.

O livro "O Príncipe" funda o pensamento político moderno porque busca oferecer repostas novas a uma situação histórica nova. Maquiavel inova, pois diferentemente de outros intelectuais contemporâneos que buscam compreender essa nova conjuntura a eles apresentada lendo autores antigos, ele faz a observação direta dos acontecimentos que ocorriam diante de seus olhos. Dessa forma, Maquiavel conseguiu uma obra que não apenas analisa a situação da sua Itália, mas apresentava as soluções para o sucesso de um governo e juntamente a isso lança as bases da política moderna.

Se compararmos o pensamento político proposto por Maquiavel em "O Príncipe" podem ser elencados ao menos quatro pontos que apontam uma ruptura "maquiaveliana" com o que estava há séculos proposto. Primeiramente, podemos ver que Maquiavel não admite a existência de um fundamento anterior à política. Dessa forma, ele contrapõe com a ideia corrente de que Deus fundamenta tudo que existe, inclusive a política. Nesse sentido Maquiavel entende que a cidade vive em constantes disputas entre quem exerce o poder e quem é comandado.

Esta divisão evidencia que a cidade não é uma comunidade homogênea nascida da vontade divina, da ordem natural ou da razão humana. Na verdade, toda cidade, segundo Maquiavel, é tecida de lutas internas que a obrigam a instituir algo que tente organizá-la. Na busca de controlar as forças existentes o homem criou o poder político.

Dessa forma, segundo Nicolau Maquiavel, a política resulta da ação social a partir das divisões sociais. Além disso, Maquiavel não aceita a ideia de boa comunidade política constituída para o bem comum e a justiça. Como vemos o ponto de partida para ele é a divisão entre quem são os mandatários e os mandados. Para Maquiavel essa ideia de entender sociedade como una e indivisa constitui apenas uma máscara que 
recobre a realidade social, para assim enganar oprimir e comandar o povo, fazendo entender que os interesses dos grandes e pequenos fossem os mesmos e todos vivessem em harmonia:

A finalidade da política não é como diziam os pensadores gregos, romanos e cristãos, a justiça e o bem comum, mas como sempre souberam os políticos, a tomada e manutenção do poder. $\mathrm{O}$ verdadeiro príncipe é aquele que sabe tomar e principalmente conservar o poder e que, para isso, jamais se alia aos grandes, pois estes são seus rivais e querem o poder para si, mas deve aliar-se ao povo, que espera do governante a imposição de limites ao desejo de opressão e mando dos grandes. A política não é lógica racional da justiça e da ética, mas a lógica da força transformada em lógica do poder. (CHAUÍ, 2010)

Entende-se então que a finalidade de o governo não é, segundo "O Príncipe", o bem comum e a justiça. Isso significa que Maquiavel recusa a figura do bom governo e virtuoso, portador das virtudes cristãs. O governante necessita de qualidades que o fazem tomar e manter o poder, mesmo que para isso este tenha que usar de meios inescrupulosos como a violência, a mentira, a astúcia e a força.

Não pode e não deve um príncipe prudente manter a palavra empenhada quando tal observância se volte contra ele e hajam desaparecido as razões que a motivam. Nas ações de todos os homens, especialmente os príncipes, os fins é que contam. Faça, pois, o príncipe tudo para alcançar e manter o poder; os meios de que se vale sempre serão julgados honrosos e louvados por todos vulgo atenta sempre para aquilo que parece ser e para os resultados. (MAQUIAVEL, 1513)

Nesse sentido, é explícito que dentro da política segundo Maquiavel os objetivos principais de um governante (conquista e manutenção do poder) devem sempre ser buscados mesmo quando esta busca ultrapasse os limites da moral e da ética. Assim, o sucesso de um governante não poder ser mensurado pelos seus atos e sim pelas suas conquistas. A virtude política de um príncipe aparecerá na qualidade das instituições que souber criar e manter e na capacidade que tiver para enfrentar as ocasiões adversas.

Ao apoderar-se dum Estado o conquistador deve determinar as injúrias que precisa levar a efeito, e executá-las todas de uma só vez, para não ter que renová-las dia a dia. Deste modo, poderá incutir confiança nos homens e conquistar-Ihes o apoio beneficiando-os. Quem age por outra forma, ou por timidez ou por força de maus conselhos, tem sempre necessidade de estar com a faca na mão e não poderá nunca confiar em seus súditos, porque estes, por sua vez, não se podem fiar nele, mercê das suas recentes e contínuas injúrias. As injúrias devem ser feitas todas de uma vez, a fim de que, tomando-se lhes menos o gosto, ofendam menos. E os benefícios devem ser realizados pouco a pouco, para que sejam mais bem saboreados (MAQUIAVEL, 1513)

Dado o exposto, percebe-se que a obra "O Príncipe" inaugura uma nova forma de conceber política. Nicolau Maquiavel inovou ao observar que havia uma distância enorme entre o ideal de política e a realidade política. Nesse sentido, o livro “O Príncipe" trata a política como ela se dá, ou seja, sem pretender fazer uma teoria da política ideal, mas, ao contrário, compreender e esclarecer a política real.

Maquiavel afastou-se da concepção idealizada de política. Centrou sua reflexão de que o poder político tem como função regular as lutas e tensões entre os grupos sociais, visto que a sociedade é composta por grupos heterogêneos em constantes disputas principalmente pelo poder.

Para Frosini (2017) Essas lutas são constantes e por isso é utópico a ideia de um governo que busca o bem comum para todos. A política expressa em "O Príncipe" tem como objetivo a manutenção do poder do Estado. E para manter o poder o governante deve lutar com todas as forças possíveis, sempre atento as correlações de forças que se mostram a cada instante, com o intuito de tomar o poder ou desestabilizá-lo. Dessa forma, a ação política não cabe nos limites do juízo moral e de valores éticos, cabe ao governante fazer 
tudo aquilo que ele entenda que seja interessante para conservar o poder, as decisões de governante atendam a lógica do poder.

\title{
Virtú X Fortuna
}

Como já foi observada, a tradição grega tornara ética e política, inseparáveis e que posteriormente a tradição romana colocara essa identidade da ética e da política na pessoa virtuosa do governante e que a tradição cristã transformara a pessoa política num corpo místico sacralizado que encarnava a vontade de Deus e a comunidade humana.

Hereditariedade, personalidade e virtude formavam o centro da política, orientada pela ideia da justiça do bem comum. Esse conjunto de ideias e imagens é demolido por Maquiavel. Um dos aspectos da concepção maquiaveliana que melhor revela essa demolição encontra-se na figura do príncipe virtuoso. (CHAUÍ, 2010)

Determinar exatamente qual o sentido da palavra virtù é algo muito complexo. O primeiro empecilho na determinação deste termo é de grande variedade de sentidos que ele apresenta. Do mesmo modo que hoje se tem uma mesma palavra com um uma variedade de sentidos, ele parece ocorrer com o termo virtù.

Observando o contexto e o objetivo da obra de Maquiavel, podemos entender que virtù está relacionado diretamente com as qualidades excepcionais que um príncipe deve ter. As qualidades que um governante tem constituem assim a sua virtù que, por sua vez, deve se impor aos problemas enfrentados na administração para conquistar e manter o poder.

A virtù, como característica essencial ao um governante, tem um sentindo muito mais prático que moral ou ético em "O Príncipe". Para Maquiavel um governante virtuoso deve tomar ações nem sempre que condizem com os princípios éticos e morais. Um príncipe deve estar sempre atento, segundo ele, em manter seu poder mesmo que para isso tome ações imorais. A virtù é dessa forma a flexibilidade de um administrador frente ao moral e ao imoral com o objetivo de conquistar e manter seu poder. A virtù de um príncipe não pode ser julgada pelo meio que foi realizada e sim pelo objetivo final:

\begin{abstract}
Existem duas formas de se combater: uma, pelas leis, outra, pela força. A primeira é própria do homem; a segunda, dos animais. Como, porém, muitas vezes a primeira não seja suficiente, é preciso recorrer à segunda. Ao príncipe torna-se necessário, porém, saber empregar convenientemente o animal e o homem. Isto foi ensinado à socapa aos príncipes, pelos antigos escritores, que relatam o que aconteceu com Aquiles e outros príncipes antigos, entregues aos cuidados do centauro Quiron, que os educou. É que isso (ter um preceptor metade animal e metade homem) significa que o príncipe sabe empregar uma e outra natureza. E uma sem a outra é a origem da instabilidade. Sendo, portanto, um príncipe obrigado a bem servir-se da natureza da besta, deve dela tirar as qualidades da raposa e do leão, pois este não tem defesa alguma contra os laços, e a raposa, contra os lobos. Precisa, pois, ser raposa para conhecer os laços e leão para aterrorizar os lobos. (MAQUIAVEL, 1513)
\end{abstract}

Pode-se perceber que virtù não consiste em um conjunto fixo de qualidades morais que ele oporá às circunstâncias encontradas em seu governo. A virtù é a capacidade do príncipe para ser flexível, independentemente das questões morais e ética, aos obstáculos enfrentados na conquista e manutenção do poder.

Compreendendo, mesmo que superficialmente o que para Maquiavel significa virtù, partiremos para outro termo muito utilizado por este pensador florentino e que tem relação direta com o primeiro termo 
analisado, a fortuna. A fortuna, assim como a virtù, não tem uma acepção única. Seus possíveis significados são vagos, implicando, no mais das vezes em: acaso, sorte, chance, jogo de azar ou sucesso.

Entretanto, para compreender qual o sentido de fortuna é necessário buscar como esse termo era posto naquele contexto histórico. Enquanto para os romanos a fortuna era vista como uma deusa boa, uma aliada potencial, cuja simpatia era necessária atrair, pois a fortuna possuía os bens que todos os homens desejavam possuir: honra, riqueza, a glória e o poder. Com o cristianismo nasce um novo significado para fortuna, esta poderia ser vista como um "poder cego" imparcial que distribui seus bens de forma aleatória.

Nicolau Maquiavel, bebendo nessas duas fontes vai dar uma nova interpretação ao termo fortuna. Para ele o virtuoso príncipe é aquele que consegue atrair a fortuna para si criando condições para que a mesma ocorra e principalmente não desperdiçando quando esta aparece. Nesse sentido ele busca o controle do incontrolável (segundo a concepção cristã):

Penso poder ser verdade que a fortuna seja árbitra de metade de nossas ações, mas que, ainda assim, ela nos deixe governar quase a outra metade. Comparo-a a um desses rios impetuosos que, quando se encolerizam, alagam as planícies, destroem as árvores, os edifícios, arrastam montes de terra de um lugar para outro: tudo foge diante dele, tudo cede ao seu ímpeto, sem poder obstar-lhe e, se bem que as coisas se passem assim, não é menos verdade que os homens, quando volta a calma, podem fazer reparos e barragens, de modo que, em outra cheia, aqueles rios correrão por um canal e o seu ímpeto não será tão livre nem tão danoso. Do mesmo modo acontece com a fortuna; o seu poder é manifesto onde não existe resistência organizada, dirigindo ela a sua violência só para onde não se fizeram diques e reparos para contê-la. (MAQUIAVEL, 1513)

A fortuna é sempre favorável a quem souber agarrá-la. Esta se oferece como um presente a quem poder dobrá-la e/ou vencê-la. E para conquistar a inconstante fortuna, no lugar da estável virtude moral, ele introduz a virtude política que consiste na flexibilidade, independentemente de valores morais e éticos. Dessa forma, um governante deve mentir ou ser honrado dependendo da ocasião que lhe é apresentada. Maquiavel, assim, introduz a virtude política como a astúcia e a capacidade de se adaptar e sair vencedor das circunstâncias apresentadas e conseguir agarrar a fortuna.

\section{A relação entre Ética e Política}

A seguir vamos esboçar o pensamento de Maquiavel em poucas linhas. Talvez o maior legado de Maquiavel para o pensamento filosófico-político foi fazer a separação entre "ética e política". No pensamento clássico a política e a ética caminham juntas. A ética está a serviço da política para proporcionar o "bem comum".

Dissemos que a tradição grega tornara ética e política inseparáveis, que a tradição romana colocara essa identidade da ética e da política na pessoa virtuosa do governante e que a tradição cristã transformara a pessoa política num corpo místico sacralizado que encarnava a vontade de Deus e a comunidade humana. Hereditariedade, personalidade e virtude formavam o centro da política, orientada pela ideia de justiça e bem comum. Esse conjunto de ideias e imagens é demolido por Maquiavel. (CHAUI, 1998)

É fundamental entendermos a relação que existe entre virtude e fortuna no pensamento de Maquiavel, e, sendo assim, compreender sua ruptura entre ética e política. A questão da ética vista em sua forma tradicional diferenciava entre o que "estava ou não" em nosso poder para as decisões. O que "está em nosso poder" faz parte das decisões racionais e livres, portanto, faz parte da "virtude", e o que "não está em 
nosso poder" (que significa "o conjunto de circunstâncias externas que agem sobre nós e determinam nossa vontade e nossa ação") para as decisões faz parte da "fortuna".

A ética sempre foi vista como uma inseparável oposição entre virtude-fortuna (CHAUI, 1998). Como ética e política não se separam no pensamento antigo, “(...) o governante virtuoso é aquele cujas virtudes não sucumbem ao poderio da caprichosa e inconstante fortuna" (CHAUI, 1998).

Outro conceito importante faz parte do pensamento de Maquiavel. É sobre visão da tomada e manutenção do poder. Neste ponto seria interessante observar que ele vai separar um estado teocrático de um estado laico, que garantirá a manutenção da política como um fim em si mesma. O fim último de um governante é manter a unidade do seu domínio. O poder se faz em uma lógica do poder pelo poder.

Para tanto, ele deve usar em casos extremos, da força, ou de quaisquer meios viáveis para alcançar este objetivo. Kritsch (2011) nos diz sobre a questão da manutenção do poder: “(...) a condição de durabilidade do Estado são as armas, que podem ser próprias ou de terceiros”. Para Maquiavel, “(...) a ordem equivale à violência administrada". A condição limite para a ação política é a violência. Se necessário for usar as armas, elas serão as condições limites. Maquiavel (1973) nos diz que “(...) cada príncipe deve desejar ser tido como piedoso e não como cruel: apesar disso, deve cuidar de empregar convenientemente essa piedade".

No que consistiria essa piedade? Seria para Maquiavel (1973): “Não deve, portanto, importar ao príncipe a qualificação de cruel para manter os seus súditos unidos e com fé, porque, com raras exceções, é ele mais piedoso do que aqueles que por muita clemência deixam acontecer desordens (...)":

Podemos pensar que em Maquiavel existe um "dualismo ético"? Uma ética que regula a ação política, e uma ética que regula as ações morais individuais? Na primeira, as ações que se fizerem necessárias serão tomadas visando à manutenção do Estado, sejam até, em casos extremos, inescrupulosas ou violentas. Esta "ética política" não teria relação com a ética tradicional no sentido grego ou cristão de governar para o bem comum ou para exercer as virtudes cristãs.

Na segunda, uma ética pessoal voltada para a vida cotidiana do cidadão, onde aí sim ele explorará todas as virtudes éticas. Para Kritsch (2011) não há esta divisão! “(...) uma ética individual pode produzir santos. Mas não produz política". Existe no âmbito da política interesses que são de naturezas mais abrangentes do que os individuais. Esta seria a visão de Maquiavel (1973) que nos diz: "e um homem que quiser fazer profissão de bondade é natural que se arruíne entre tantos que são maus. Assim é necessário a um príncipe, para se manter, que aprenda a poder ser mau (...)". Conforme Kritsch (2011), isto não teria a intenção de fazer:

(...) uma distinção entre a ética cristã e a ética política, e sim de abrir uma nova perspectiva de pensar a ética (...) assim como a ética do cristão, para Maquiavel, não se confunde com a ética do político, o bem-estar do Estado tem exigências diferentes das exigências do individual. (KRITSCH, 2011)

Estes conceitos trazem a noção de um governo utilitarista, ou desumano? Esta pergunta é muito difícil de ser respondida. Na prática as decisões políticas podem ser vistas de formas diferentes. Em cada caso 
particular, e visando um objetivo maior que é a manutenção do Estado, as decisões políticas seguirão a sua própria ética. Esta é uma visão da política pela política.

\section{CONCLUSÕES}

O pensamento de Maquiavel é uma ruptura com o pensamento filosófico sobre a política em seu tempo. O contexto político de Maquiavel o fez pensar uma forma inovadora de escrever sobre a política. Talvez o maior impacto de sua obra é como se posicionar frente à ética na política. Para tanto, ele faz a divisão - ou uma nova forma de pensar ética, como já dito anteriormente - entre os valores tradicionais e cristãos e as contingências do Estado para a manutenção do seu poder.

Diversamente dos teólogos, que partiram da bíblia e do direito romano para formular teorias políticas, e diferentemente dos seus contemporâneos renascentistas que partiram de obras de filósofos greco-romanos para construir suas teorias políticas, Maquiavel parte da experiência do seu tempo para a concepção de suas teorias. Esse gênio florentino do pensamento político moderno foi conselheiro dos governantes de sua terra, acompanhou de perto as lutas europeias de centralização monárquica, viu o ressurgimento da vida urbana europeia e, com ela, a ascensão da burguesia comercial das grandes cidades e, sobretudo, viu a fragmentação da Itália, dividida em reinos, ducados, república e Igreja.

A compreensão dessas experiências históricas por ele vividas e a interpretação do sentido delas o conduziram ao entendimento de que as ideias políticas antigas e medievais não eram capazes de abarcar verdadeiramente o que é o poder e que uma nova concepção da sociedade e da política se tornava necessária, sobretudo em seu país.

Entendemos que o conceito de fazer política em Maquiavel é deixar a "política fazer política". Às vezes, frente a nossa moralidade, medidas de Estado, que geram desconforto, são para benefícios coletivos. Acreditamos que Maquiavel tem este entendimento, pois vislumbra em seu pensamento o bem-estar de seu povo. Ele mesmo chega a dizer que a Piedade é não deixar acontecer a desordem.

A concepção que Nicolau Maquiavel extrai da política, na verdade retira a máscara de hipocrisia que adornava o pensamento político até então. Maquiavel não apenas define política, atividade, já realizada por uma série de pensadores antes dele, mas agora Maquiavel deixa explícito que a política tem um objetivo que justifica as ações enquanto se está no comando, que é a manutenção do poder.

Esse grande pensador dá as bases para o pensamento político moderno porque busca oferecer respostas novas a uma situação histórica nova, os pensadores contemporâneos seus tentavam compreender lendo autores antigos deixando de lado a observação direta dos acontecimentos que ocorriam diante de seus olhos.

Maquiavel, como afirma Marilena Chauí, também inova ao desligar o poder político de fundamentos não políticos (Deus, natureza, razão) e ao articulá-lo à divisão social entre os grandes e o povo, Maquiavel abriu caminho para uma discussão essencial para o pensamento político moderno: a ideia de soberania, o sumo poder, o poder supremo. No entanto, ele se preocupa em afirmar que soberano não é uma pessoa e 
sim o poder político, independente do poder religioso e do poder econômico com a função primordial de manter seu poder e consequentemente o Estado por ele governado.

Nesse sentido, compreender a política em seu âmago, realmente, merece considerarmos os dois "lados da moeda": quando se governa e quando se é governado. No primeiro caso, nem sempre as medidas serão populares nem talvez possam ser responsáveis e éticas na visão maquiavélica. Entretanto, as soluções e definições de política concebidas por Maquiavel são frutos de sua experiência histórica e, assim, devem ser observadas. Maquiavel é um homem de seu tempo e buscou soluções para os problemas vividos por sua Itália. Nesse sentido é válido buscar em suas concepções a essência e não as colocar à prova na atual conjuntura.

Enfim, o pensamento político moderno e crítico, precisam decifrar os enigmas propostos pela obra tão complexa de Nicolau Maquiavel, além disso, resgatá-lo sem preconceitos e reconhecer o legado de Maquiavel, gênio do pensamento político, um cidadão sem fortuna, mas um intelectual de grandes virtudes.

\section{REFERÊNCIAS}

ARANHA, M. L. A.; MARTINS, M. H. P.. Filosofando: introdução à filosofia. São Paulo: Moderna, 2000.

ARENDT, H. A condição humana. São Paulo: Forense Universitária, 2014.

BONORA, D. K.; PRADO, G. S.. A importância de Nicolau Maquiavel para interpretar o cenário político do brasil contemporâneo. In: JORNADA INTEGRADA DO CURSO DE DIREITO E CIÊNCIAS CONTÁBEIS DO CENTRO UNIVERSITÁRIO. Anais. Cascavel: FAG, 2016.

CHAUÍ, M.. Iniciação à Filosofia. São Paulo: Ática, 2010.

COTRIM, G.. Fundamentos da Filosofia. São Paulo: Saraiva, 2010.

KRITSCH, R.. Maquiavel e a construção da política. Lua Nova, São Paulo, n.53, p.181-190, 2001. DOI:

http://doi.org/10.1590/S0102-64452001000200009

DIAS, T.. Hannah Arendt contra a differentia specifica. Kriterion, Belo Horizonte, v.59 n.141, 2018. DOI: http://doi.org/10.1590/0100-512x2018n14115td

FAVERO, R. C.. Sartre: uma filosofia em defesa da liberdade e da ética. R. Inter. Interdisc. INTERthesis, Florianópolis, v.15, n.2, p.19-37, 2018. DOI: http://doi.org/10.5007/1807$\underline{1384.2018 v 15 n 2 p 19}$

FONSECA, J. J. S.. Metodologia da pesquisa científica. Fortaleza: UEC, 2002.

FROSINI, F.. O pensamento revolucionário de Nicolau Maquiavel. Rev. bras. Ci. Soc., São

Paulo, v.32 n.93, 2017. DOI:

http://doi.org/10.17666/329315/2017
GALLO, S.. Deleuze e a educação. São Paulo: Autêntica, 2008.

GIL, A. C.. Metodologia do ensino superior. 4 ed. São Paulo: Atlas, 2011.

LARIVAILLE, P.. A Itália no Tempo de Maquiavel. São Paulo: Companhia das Letras, 1991.

MAQUIAVEL, N.. Discorsi sopra la prima deca di Tito Lívio. In: VIVANTI, C.. Opere Torino Einaudi-gallimard. 1997.

MAQUIAVEL, N.. O Príncipe. São Paulo: Abril Cultural, 1973.

MAQUIAVEL, N.. O Príncipe. 10 ed. São Paulo: Civilização Brasileira, 1985.

PEDRO, A. P.. Ética, moral, axiologia e valores: confusões e ambiguidades em torno de um conceito comum. Kriterion, Belo Horizonte, v.55, n.130, 2014. DOI: http://doi.org/10.1590/S0100-512X2014000200002

RIDOLFI, R.. Biografia de Nicolau Maquiavel. Rio de Janeiro: Musa, 2003.

ROEPKE, A. S.. A construção do conceito de Estado em Maquiavel e Hobbes. Universidade Federal de Santa Catarina, 1997.

SILVA, C. E.. Elaboração de TCC e publicação de artigos: for starters. Aracaju: Sustenere Publishing, 2018.

SILVA, R.. Maquiavel e o conceito de liberdade em três vertentes do novo republicanismo. Rev. bras. Ci. Soc., São Paulo, v.25, n.72, 2010. DOI: http://doi.org/10.1590/S010269092010000100004

A CBPC - Companhia Brasileira de Produção Científica (CNPJ: 11.221.422/0001-03) detém os direitos materiais desta publicação. Os direitos referem-se à publicação do trabalho em qualquer parte do mundo, incluindo os direitos às renovações, expansões e disseminações da contribuição, bem como outros direitos subsidiários. Todos os trabalhos publicados eletronicamente poderão posteriormente ser publicados em coletâneas impressas sob coordenação da Sapientiae Publishing, da Companhia Brasileira de Produção Científica e seus parceiros autorizados. Os (as) autores (as) preservam os direitos autorais, mas não têm permissão para a publicação da contribuição em outro meio, impresso ou digital, em português ou em tradução. 